\title{
Modeling Mortality of Individual Trees in a Seasonal Semi-Deciduous Forest
}

Lívia Thaís Moreira de Figueiredo ${ }^{1}$ (D) 0000-0002-0339-6528

Carlos Pedro Boechat Soares ${ }^{2}$ (1) 0000-0001-6475-3376

Renato Vinícius Oliveira Castro 3 (1) 0000-0001-9018-7793

Helio Garcia Leite ${ }^{2}$ (1) 0000-0002-6357-9174

Agostinho Lopes de Souza $^{2}$ (10) 0000-0003-0205-2392

Gilson Fernandes da Silva ${ }^{4}$ (i) 0000-0001-7853-6284

Carlos Moreira Miquelino Eleto Torres² (10) 0000-0003-0255-2637

\begin{abstract}
The objective of this study was to assess and compare two methodologies to predict the mortality of individual trees in a seasonal semi-deciduous forest located in the municipality of Viçosa, Minas Gerais, Brazil. The data came from 10 permanent plots and were randomly divided into two groups: fitting (6 plots) and validation (4 plots). When assessing Methodology 1, the mortality was considered a dichotomous variable in a logistic model, assuming a value of 1 for a dead tree and 0 for a living tree. In Methodology 2, the mortality probability was estimated by the group of trees for each plot and for each measurement interval. After the analysis, it was observed that Methodology 2 provided more consistent mortality estimates when compared to the mortality estimated by Methodology 1.
\end{abstract}

Keywords: probability of mortality, uneven-aged forest, growth models.

\section{INTRODUCTION AND OBJECTIVES}

Tree mortality is an important component in forest dynamics processes and one of the least understood. Modeling the tree mortality is critical to understand the status and evolution of the forest, and therefore, an essential component of growth and production models (Crecente-Campo et al., 2009; Flewelling \& Monserud, 2002; Ma \& Lei, 2015).

Although the tree mortality prediction is considered one of the most difficult tasks in growth modeling (Hasenauer, 2006), it has significant implications for long-term growth estimates (Weiskittel et al., 2011). Since irregular mortality is difficult to predict and estimate, mortality models usually estimate only the regular mortality, i.e. that which is caused by suppression and competition between trees (Monserud, 1976).
Prediction of regular mortality can be performed: based on the physiological conditions of the tree; by using competition indices associated with probability density functions; and by determining the mortality probability within a group of trees with similar characteristics (Campos \& Leite, 2017; Glover \& Hool, 1979).

According to Vanclay (1994), logistic function adjusted to individual tree data may be the best way to model mortality in tropical forests. In this case, the mortality estimate is done by considering it as a dichotomous or binomial variable, which assumes a value of 0 for the living tree and 1 for the dead tree (Monserud, 1976; Soares et al., 2015; Yao et al., 2001).

The mortality probability of a tree group can alternatively be estimated by diameter classes and associated with forest

\footnotetext{
${ }^{1}$ Universidade Federal do Pará (UFPA), Altamira, PA, Brasil

${ }^{2}$ Universidade Federal de Viçosa (UFV), Viçosa, MG, Brasil

${ }^{3}$ Universidade Federal de São João del-Rei (UFSJ), Sete Lagoas, MG, Brasil

${ }^{4}$ Universidade Federal do Espírito Santo (UFES), Alegre, ES, Brasil
} 
variables in a regression model. This method was used by Martins (2011) in a study aimed at modeling individual tree level growth in commercial eucalyptus plantations.

There are few studies on individual tree-level mortality modeling in natural forests in Brazil. Notably, the study by Castro et al. (2015) estimated the mortality of individual trees in a natural forest using artificial neural networks, and Soares et al. (2015) by the logistics function.

The low number of modeling studies on individual trees in natural forests with high species numbers is possibly due to different mortality behaviors among species, as well as the lack of adequate data for modeling (Castro et al., 2015; Rossi et al., 2007; Vanclay, 1994).

Given the above, the objective of this study was to assess and compare two methodologies for predicting the mortality of individual trees in a seasonal semi-deciduous forest, more specifically, one method based on the use of the logistic function and the other methodology based on the probability of mortality for tree groups with regression models.

\section{MATERIALS AND METHODS}

\subsection{Data}

Data from 10 permanent plots were used in this study. The plots were installed in a montana seasonal semi-deciduous forest fragment, known as Silviculture Forest, located in Viçosa, Minas Gerais $\left(20^{\circ} 45^{\prime} \mathrm{S}\right.$ and $\left.42^{\circ} 51^{\prime} \mathrm{W}\right)$. The forest fragment has approximately $17 \mathrm{ha}$ and is in a medium succession stage (Figueiredo et al., 2013).

The permanent plots have a rectangular shape and a fixed area of $1000 \mathrm{~m}^{2}(20 \times 50 \mathrm{~m})$. In each plot, the diameter at breast height (DBH - diameter at $1.30 \mathrm{~m})$, the total height $(\mathrm{TH})$, and the base to crown height - stem height $(\mathrm{SH})$ were measured and all tree individuals with $\mathrm{DBH} \geq 5 \mathrm{~cm}$ were identified. The individuals were classified in ecological groups according to the classification proposed by Gandolfi et al. (1995). The measurements were made in the years of 1994, 1997, 2000, 2004, and 2008. The characterization of the fragment is presented in Table 1.

Table 1. Characterization of the seasonal semi-deciduous forest fragment located in the municipality of Viçosa, MG, Brazil, in interim years 1994 and 2008.

\begin{tabular}{|c|c|c|c|c|c|}
\hline \multirow{2}{*}{ Variable } & \multicolumn{5}{|c|}{ Measurement year } \\
\hline & 1994 & 1997 & 2000 & 2004 & 2008 \\
\hline Number of stems (per ha) & 1,521 & 1,540 & 1,497 & 1,474 & 1,492 \\
\hline Density (trees ha $\left.{ }^{-1}\right)$ & 1,379 & 1,383 & 1,331 & 1,307 & 1,326 \\
\hline Quadratic Diameter $(\mathrm{cm})$ & 14.2 & 14.6 & 14.9 & 15.0 & 15.3 \\
\hline Basal area $\left(\mathrm{m}^{2} \mathrm{ha}^{-1}\right)$ & 24.1 & 25.9 & 26.2 & 26.2 & 27.5 \\
\hline Volume $\left(\mathrm{m}^{3} \mathrm{ha}^{-1}\right)$ & 235.5 & 275.2 & 291.4 & 323.9 & 342.1 \\
\hline Minimum DBH $(\mathrm{cm})$ & 5.1 & 5.1 & 5.1 & 5.1 & 5.0 \\
\hline Average DBH $(\mathrm{cm})$ & 11.6 & 11.8 & 12.0 & 12.0 & 12.2 \\
\hline Maximum DBH $(\mathrm{cm})$ & 80.2 & 82.1 & 84.0 & 85.6 & 91.0 \\
\hline Min TH $(\mathrm{m})$ & 2.5 & 2.5 & 2.5 & 2.4 & 2.4 \\
\hline Mean TH (m) & 10.4 & 11.1 & 11.4 & 12.4 & 12.5 \\
\hline $\operatorname{Max} \mathrm{TH}(\mathrm{m})$ & 32.1 & 32.4 & 33.0 & 39.2 & 39.4 \\
\hline Botanical Families & 43 & 43 & 43 & 42 & 42 \\
\hline Botanical Genres & 100 & 98 & 99 & 99 & 103 \\
\hline Identified Species & 136 & 135 & 137 & 135 & 148 \\
\hline Unidentified species & 4 & 3 & 4 & 3 & 5 \\
\hline Shannon-Weaver Index (H') & 4.07 & 4.02 & 4.00 & 3.96 & 4.02 \\
\hline Ingrowth (ind ha-1) & - & 114 & 79 & 57 & 134 \\
\hline Dead trees (ind ha ${ }^{-1}$ ) & - & 95 & 122 & 80 & 115 \\
\hline
\end{tabular}

\subsection{Mortality modeling}

The database was separated into two groups: fit and validation. Six plots were randomly selected to adjust the mortality equations, totaling 4,746 observations ( 231 mortality cases). The remaining four plots were used to validate the model in a total of 2,831 observations (181 mortality cases).

Two methodologies for modeling the mortality probability $(M(P))$ were assessed and compared. In the first methodology (Methodology 1), mortality was considered a dichotomous or binomial variable, which assumed a value of 0 if the tree was alive and 1 if the tree died in the monitoring period. In this case, the logistic function shown by Equation 1 was used to estimate the mortality probabilities, with the parameter estimates being obtained by the Maximum Likelihood method (Hasenauer, 2006; Gujarati \& Porter, 2011; Monserud, 1976; Monserud \& Sterba, 1999;): 


$$
P(M)=\left(1+e^{\left(\beta_{0}+\beta_{1} X_{1}+\ldots \beta_{k} X_{k}\right)}\right)^{-1}+\varepsilon
$$

In which, $M(P)$ : mortality probability; $\beta_{0}, \beta_{1}, \ldots \beta_{\mathrm{k}}$ : model coefficients; $X_{1}, \ldots X_{\mathrm{k}}$ : independent variables; $\varepsilon$ : random error.

It should be noted that some trees in the studied forest had more than one stem and there was a mortality of stems, not of trees. However, as the number of mortality cases of only one of the tree stems was very low considering the total living trees, it was decided to use the term tree mortality, even for the cases in which mortality was restricted to only one of the stems.

The independent variables assessed in the mortality modeling were: i) $\mathrm{DBH}=$ diameter measured at a height of $1.30 \mathrm{~m}$, in $\mathrm{cm}$; ii) $\mathrm{TH}=$ total height, in $\mathrm{m}$; (iii) Dmean and Dmax $=$ mean diameter and maximum diameter of trees in $\mathrm{cm}$ per plot; iv) $\overline{T h}=$ average of the total tree heights of the parcels, in $\mathrm{m}$; v) Hdom = average total height of the ten trees with the largest diameter per plot, in $\mathrm{m}$; vi) $B=$ basal area in $\mathrm{m}^{2} \mathrm{ha}^{-1}$; and vii) $C I=$ competition indices.

The competition indices assessed were the independent distance indices (IDI), according to Equations 2, 3 and 4 (Castro et al., 2014; Glover \& Hool, 1979):

$$
\begin{gathered}
I D I_{1}=\frac{T h_{i}}{\overline{T h}} \\
I D I_{2}=B A I=\frac{A S i}{A S q} \\
I D I_{3}=B A I_{i}
\end{gathered}
$$

In which, $T h$ : total height of object tree stem $(\mathrm{m}) ; \overline{T h}$ : mean height of the sample unit stems (m); ASi: sectional area of the stem of the object tree, measured at $1.30 \mathrm{~m}\left(\mathrm{~m}^{2}\right) ; A S q$ : sectional area corresponding to the mean diameter $(\mathrm{q})$ of the tree stems of the plot $\left(\mathrm{m}^{2}\right) ; B A L_{\mathrm{i}}$ : sum of the sectional areas of the neighboring tree stems larger than the object tree.

The Spearman correlation between the independent model variables and the mortality probability was analyzed to select the independent model variables, as well as the statistical significance of the coefficients ( $p$-value $<0.05$ ); the coherence of the signs associated with the model coefficients and the variance inflation factor (VIF) (Gujarati \& Porter, 2011). The selection of the best equation for estimating mortality probability was based on log-likelihood statistics and the Chi-squared $\left(\chi^{2}\right)$ test $(\alpha=5 \%)$ (Gujarati \& Porter, 2011). The equations were adjusted using the Statistica 12 software (Statsoft, 2013).

For the second methodology (Methodology 2, the trees were grouped according to their diameter into $5 \mathrm{~cm}$ amplitude classes, with the lower limit of the first class defined by the minimum inclusion diameter $(5 \mathrm{~cm})$. Methodology 2 consisted of fitting regression models considering the independent variables used in Methodology 1, and the tree mortality probability estimated by diameter class for each plot and for each measurement interval, shown by Equation 5 (Castro et al., 2015):

$$
P(M)=100 \odot \frac{\left(n_{j 1}-n_{j 2}\right)-I_{j 1 j 2}}{\sum_{i=1}^{j} n_{j 1}}
$$

In which, $n_{j 1}$ : number of living trees in the $\mathrm{j}^{\text {th }}$ diameter class at the beginning of the period; $n_{j 2}$ : number of living trees in the $j^{\text {th }}$ diameter class at the end of the period; $\left(I_{j 1 j 2}\right)$ : number of individuals who joined during the period.

The selection of independent variables was performed considering also the Spearman correlation between the independent variables of the model and the mortality probability; significance and coherence of the signs associated with the model coefficients; and the VIF (Gujarati \& Porter, 2011).

Three models were adjusted and assessed in Methodology 2: multiple linear (Equation 6), logistic (Equation 7), and West (1981), according to Equation 8. The linear model was adjusted by the ordinary least squares (OLS) method and the non-linear models by the Levenberg-Marquardt algorithm using the Statistica 12 software (Statsoft, 2013).

$$
\begin{gathered}
P(M)=\beta_{0}+\beta_{1} X_{1}+\ldots+\beta_{k} X_{k}+\varepsilon \\
P(M)=\left(1+e^{\left(\beta_{0}+\beta_{1} X_{1}+\ldots \beta_{k} X_{k}\right)}\right)^{-1}+\varepsilon \\
P(M)=\beta_{0} X_{1}^{\beta_{1}} \cdot \ldots X_{k}^{\beta_{k}}+\varepsilon
\end{gathered}
$$

In the selection of the best equation in Methodology 2 and in addition to the criteria previously cited in selecting the variables in Methodology 1, the number observed regarding the estimated number of dead trees and the correlation coefficient between the estimated and observed mortality probabilities were considered, as per (Equation 9):

$$
r_{y \hat{y}}=\frac{\operatorname{cov}(Y, \hat{Y})}{\sqrt{S^{2}(Y) S^{2}(\hat{Y})}}
$$

In which, $Y$ : observed mortality probability; $\hat{Y}$ : estimated mortality probability; cov: covariance; $S^{2}(Y)$ and $S^{2}(\hat{Y})$ : variance of $Y$ and $\hat{Y}$, respectively.

The total number of dead trees in each diameter class was obtained in Methodology 2 by multiplying the estimated 
mortality probability for each class by the total number of trees in each DBH class.

\subsection{Validation of the selected models}

The selected equations in Methodologies 1 and 2 were applied to the validation data to verify the accuracy of the two analyzed methodologies. To this end the following items were compared: i) the projected and observed data of the total number of dead individuals between each measurement period in each plot; ii) the number of dead individuals by diameter class. The projections were made for the immediate subsequent measurement, i.e. from 1994 to 1997; from 1997 to 2000 , and thus successively.

Mortality estimates were compared with the observed values using the non-parametric Kolmogorov-Smirnov (K-S) test (Sokal \& Rohlf, 1969), with its statistics given by Equation 10:

$$
d n=\operatorname{Max}\left|F_{0}(x)-F_{e}(x)\right|
$$

In which, $d n$ : is the estimated value from the K-S test; $F_{o}(x)$ : observed relative cumulative frequency; $F_{e}(x)$ : estimated relative cumulative frequency.

As a test decision rule, the null hypothesis $\left(\mathrm{H}_{0}\right.$ : estimates do not differ from observed values) was rejected for an estimated $d n$ value greater than the tabulated value ( $\alpha=5 \%)$.

In the case of Methodology 1, the validation was possible by applying a simulation routine to qualify trees as dead or alive during the monitoring periods. The simulation was performed by comparing a random number $(P(a))$ between 0 and 1 with the estimated mortality probability for each tree $(M(P))$ by the selected equation. If $M(P)>P(a)$ the tree would qualify as dead and unlisted, otherwise the tree would remain alive (Pretzsch et al., 2002). As it is a probabilistic process, the simulation routine was applied 30 times to obtain the mortality trend over time in each assessment period, and consequently an average estimate of the number of dead trees.

In Methodology 2, as described above, the number of dead trees was obtained by multiplying the mortality probability in the class (or proportion of dead trees) by the respective number of live trees at the beginning of each monitoring period.

\section{RESULTS AND DISCUSSION}

Higher tree mortality was observed in the second and fourth measurement intervals during the total monitoring period (1994-2008), according to Figure 1. No trend in mortality was observed over the monitoring period, as this may be explained due to the mortality, which is a random and difficult event to predict, and may be caused by a variety of external factors, such as density, disease, water stress, among others (Hasenauer, 2006; Weiskittel et al., 2011).

The Aparisthmium cordatum Baill. (PI), Siparuna arianeae V. Pereira (SI), Anadenanthera peregrina (L.) Speg (SI), Bathysa nicholsonii K. Schum. (SI), Casearia ulmifolia Vahl ex Vent (SI), Piptadenia gonoacantha (Mart.) J.F. Macbr. (SI), and Jacaranda macrantha Cham. (SI) species represent $43.8 \%$ of the total dead trees between 1994 and 2008. These species have the greatest need for light for their development and have low longevity under adverse conditions (Williamson et al., 1998), indicating progress in the successional stage of the forest.

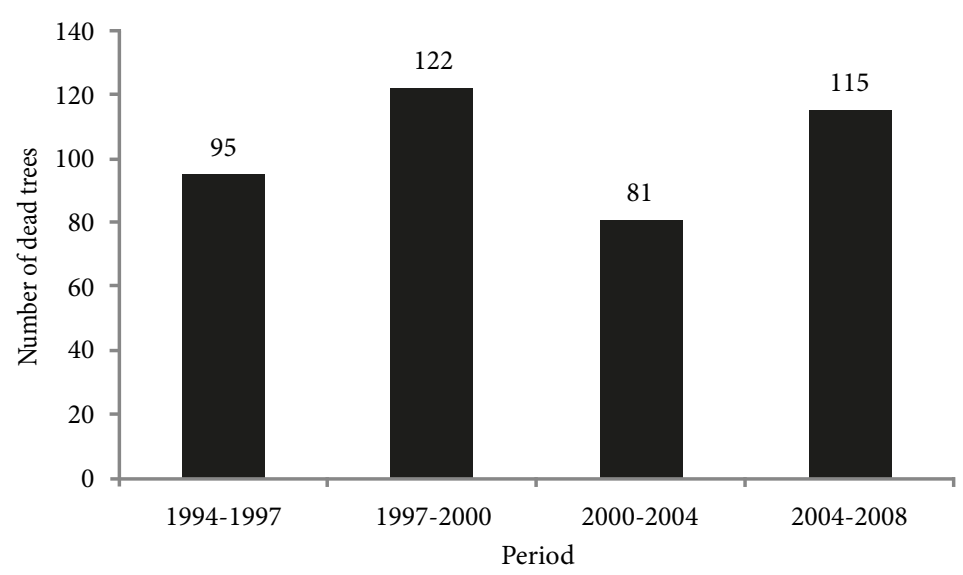

Figure 1. Number of dead trees in each monitoring period. 
Higher mortality rates for pioneer and early secondary species were also found by Ferreira et al. (1998) in areas of seasonal semi-deciduous forest. In a study performed in an area of Atlantic Forest in the municipality of Linhares (ES), Rolim et al. (1999) also observed higher mortality in pioneer species than in later species.
The total number of dead trees in this study was higher in the smallest diameter classes, according to Figure 2. In a study in a rainforest, Silva (1989) observed that mortality rates were higher in the smaller classes and that this rate tended to become almost constant in the size classes after the establishment of shade tolerant species.

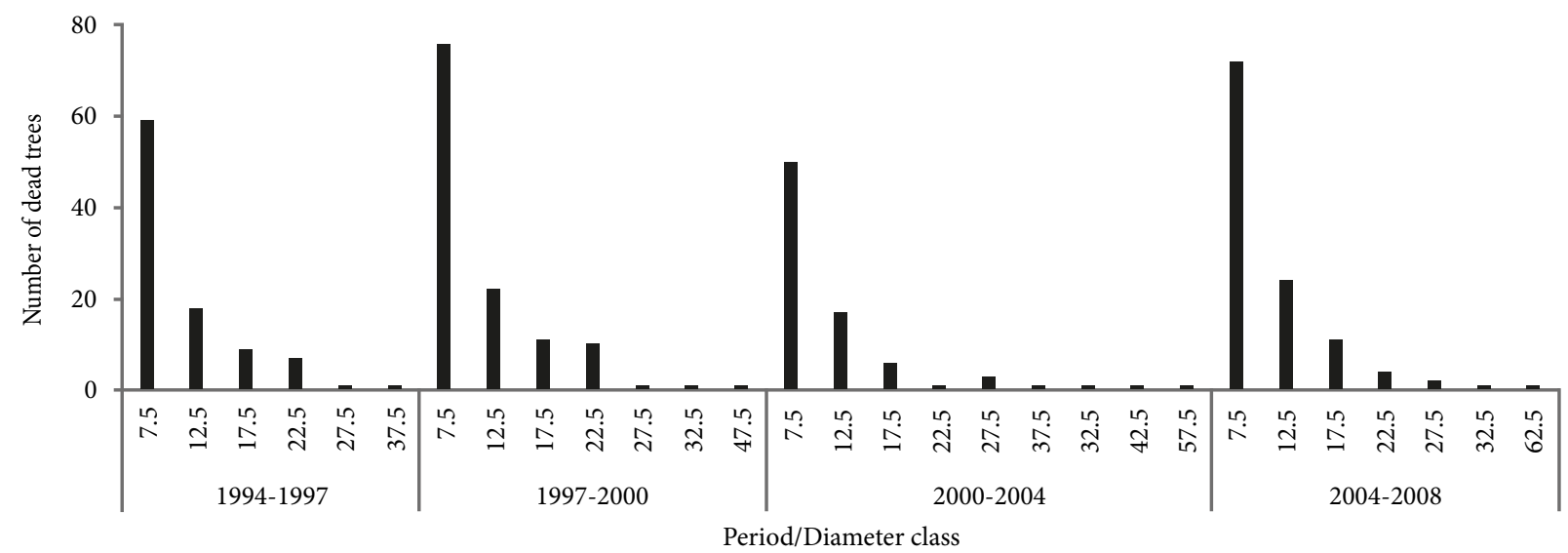

Figure 2. Number of dead trees in each monitoring period by diameter class.

The average annual mortality was $2 \%$, being higher than those found in the studies by Ferreira et al. (1998) and Rolim et al. (1999), where the annual mortality rates were $1.5 \%$, $1.22 \%$, respectively.

\subsection{Equation fitting and selection}

The independent variables selected in Methodology 1 to estimate the mortality probability per individual tree were: the maximum tree diameter (Dmax); the mean height of dominant trees (Hdom); and the competition index $\operatorname{IDI}_{1}()$, defining the following model (Equation 11):

$$
P(M)=\left(1+e^{\left(\beta_{0}+\beta_{1} D \max +\beta_{2} H \operatorname{dom}+\beta_{3} I D I_{1}\right)}\right)^{-1}
$$

All coefficients were significant $(p<0.05)$ except for parameter $\beta_{0}$, as shown in Table 2 . The signs of these coefficients indicate that trees in locations with wider diameter distribution (higher Dmax) would be subject to greater competition, resulting in a higher mortality probability. On the other hand, larger trees (higher $I D I_{1}$ ) and places with higher mean dominant height would have lower mortality probability, since they would suffer less competition from being in the upper stratum of forests and achieving better lighting conditions (Cunha \& Finger, 2013).
Table 2. Coefficients of the model, respective standard error, and $p$-value.

\begin{tabular}{cccc} 
& \multicolumn{3}{c}{ Statistics } \\
\cline { 2 - 4 } Variables/parameter & Coefficients & $\begin{array}{c}\text { Standard } \\
\text { Error }\end{array}$ & p-value \\
\hline Intercept & 0.173293 & 0.56556 & $<0.7593$ \\
Dmax & 0.009299 & 0.00473 & $<0.0497$ \\
Hdom & -0.118142 & 0.02710 & $<0.001$ \\
IDI $_{1}$ & -0.797491 & 0.18847 & $<0.001$ \\
\hline
\end{tabular}

The $I D I_{1}$ competition index selected in this study as the best index to estimate the mortality probability was also the one selected by Castro et al. (2014) to estimate tree mortality using artificial neural networks in a seasonal semi-deciduous forest. The Log-likelihood (-2Log) and the Chi-squared statistics were equal to 1799.38 and $41.69(p<0.001)$, respectively, indicating that the model significantly explained mortality variability.

The selected equation estimated $209 \pm 14$ dead trees out of a total of 231 observed dead trees. Regarding the total number of dead trees in each projection period, the mortality estimates were close to the values observed in the first monitoring periods and the equation underestimated the number of dead trees in the last measurement period, according to Figure 3. However, the Kolmogorov-Smirnov test (K-S) showed no statistically significant difference between the observed and the estimated values (K-S: $\left.0.069^{\text {ns }}\right)$. 


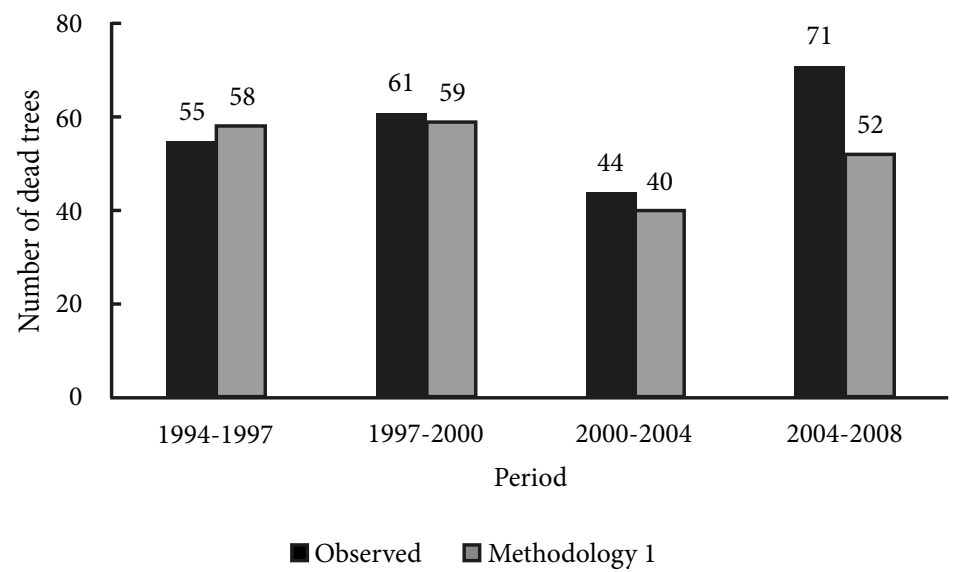

Figure 3. Numbers of dead trees observed and estimated for each period by Methodology 1 in the plots used for fitting the model.

The independent variables selected in Methodology 2 were the dominant height (Hdom) and the BAI competition index $(A S i / A S q)$. Once the $B A I$ competition index was used, the diameter variable $(D B H)$ was not used alone, given the occurrence of multicollinearity problems. However, the BAI competition index has the advantage of combining tree size and stocking density variables, which already guarantee the competitive status of each tree (Martins et al., 2011).

The coefficients of all variables in all assessed models were significant $(p<0.05)$, presented in Table 3 . The coefficients associated with the competition index variable $(B A I)$ showed negative signs, indicating that the tree is more competitive as the $B A I$ value increases, and consequently its mortality probability decreases. This trend was also observed by Monserud \& Sterba (1999) in a study to model tree mortality in natural forests in Austria.
The total number of dead trees observed from 1994 to 2008 was close to the estimates of the three models. The Equation 8 provided the closest estimates to the observed value, as well as the highest correlation (0.28) between the observed and estimated mortality probability. Thus, the mortality estimates from Methodology 2 will be obtained using Equation 8 for the purpose of comparing the mortality estimates obtained by the two assessed methodologies.

Regarding Equation 8, it is possible to observe that there was an overestimation of the number of dead trees in the first three periods, while the number of dead trees was underestimated in the last monitoring period (20042008), according to Figure 4 . The estimated number of dead trees did not differ statistically from that observed $\left(\mathrm{K}-\mathrm{S}=0.073^{\mathrm{ns}}\right)$.

Table 3. Equations parameters estimates and mortality probability statistics models for tree group (Methodology 2), in a seasonal semideciduous forest in the municipality of Viçosa, Minas Gerais, Brazil.

\begin{tabular}{|c|c|c|c|c|c|c|}
\hline \multirow{2}{*}{ Equation } & \multirow{2}{*}{ Parameter/Variables } & \multirow{2}{*}{ Coefficients } & \multicolumn{2}{|c|}{ Statistics } & \multicolumn{2}{|c|}{ Adjustment } \\
\hline & & & Standard error & $p$-value & $\mathbf{N}$ & $\mathbf{r}_{\mathrm{yy}}$ \\
\hline \multirow{3}{*}{6} & $\beta_{0}$ & 0.136263 & 0.00618 & $<0.001$ & \multirow{3}{*}{214} & \multirow{3}{*}{0.23} \\
\hline & Hdom & -0.00274 & 0.00025 & $<0.001$ & & \\
\hline & $B A I$ & -0.00455 & 0.00045 & $<0.001$ & & \\
\hline \multirow{3}{*}{7} & $\beta_{0}$ & -1.25011 & 0.103301 & $<0.001$ & \multirow{3}{*}{242} & \multirow{3}{*}{0.26} \\
\hline & Hdom & -0.05219 & 0.004307 & $<0.001$ & & \\
\hline & $B A I$ & -0.20158 & 0.019106 & $<0.001$ & & \\
\hline \multirow{3}{*}{8} & $\beta_{0}$ & 3.50915 & 1.067401 & $<0.001$ & \multirow{3}{*}{237} & \multirow{3}{*}{0.28} \\
\hline & Hdom & -1.29477 & 0.097402 & $<0.001$ & & \\
\hline & $B A I$ & -0.15405 & 0.013972 & $<0.001$ & & \\
\hline
\end{tabular}

$\mathrm{N}$ : number of estimated dead trees; $r_{y \hat{y}}:$ correlation coefficient between the estimated and observed mortality probabilities. 


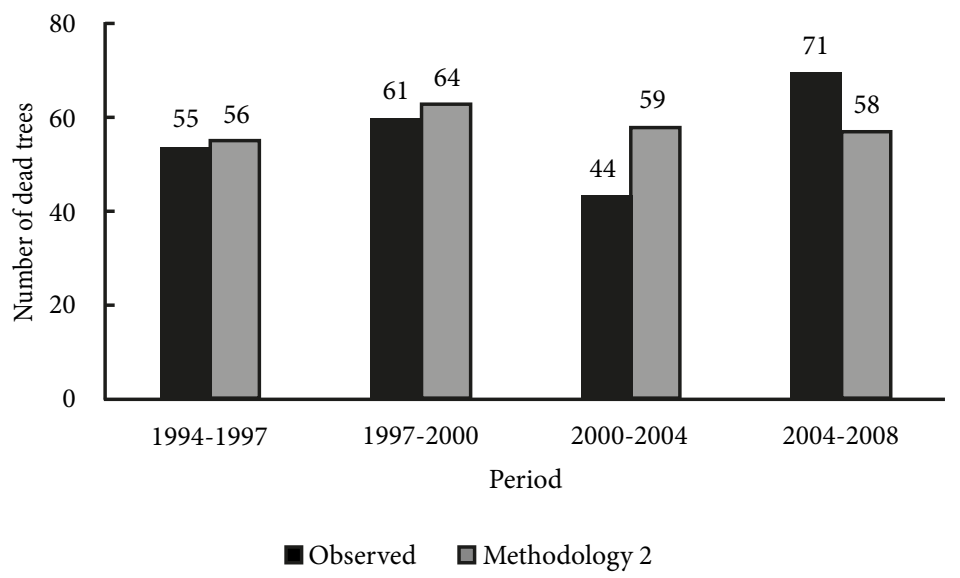

Figure 4. Number of dead trees observed and estimated by period considering the Equation 8 applied to the plots used in the process of fitting equations.

Despite less understanding of the influence of biotic and abiotic factors on native forests, as well as the limited database (Rossi et al., 2007), it was possible to obtain consistent estimates of tree mortality using Methodology 2.

\subsection{Methodologies validation}

The previously selected logistic function from Methodology 1 and Equation 8 (selected as the best model for estimating mortality according to Methodology 2) were used to compare and verify the accuracy of the methodologies analyzed in the tree mortality modeling.
The tendency observed in the validation plots was to underestimate the number of dead trees in both methodologies, according to Figure 5. The mortality estimates of Methodology 1 in these plots were statistically different from the observed values $\left(K-S=0.260^{*}\right)$, while the estimated values for Methodology 2 did not differ statistically from those observed $\left(K-S=0.150^{n s}\right)$.

Table 4 shows the confidence interval for the mortality estimates of the Methodology 1 and the number of dead trees estimated by Methodology 2. The number of trees classified as dead in the validation plots was $114 \pm 8.0$ trees for Methodology 1, and 144 trees for Methodology 2, out of a total of 181 dead trees observed.

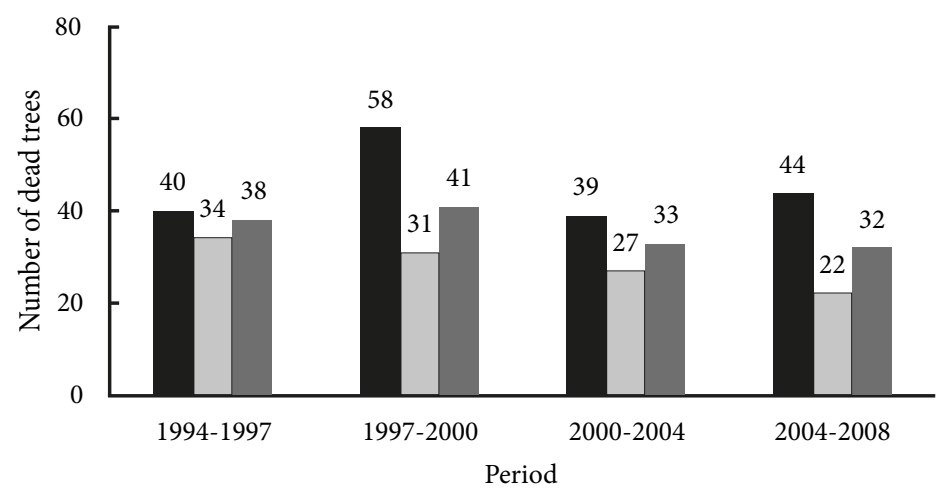

E Observed $\square$ Methodology $1 \square$ Methodology 2

Figure 5. Number of dead trees observed and estimated by period for methodologies 1 and 2 in the validation process. 
Table 4. Number of dead trees observed and estimated in each assessed methodology for each model validation plot in each one of the monitoring periods.

\begin{tabular}{ccccc}
\multirow{2}{*}{ Plot } & Period & \multicolumn{3}{c}{ Number of dead trees } \\
\cline { 3 - 5 } 3 & & Observed & Methodology 1 & Methodology 2 \\
\multirow{3}{*}{3} & $1994-1997$ & 14.0 & $12.0 \pm 3.0^{*}$ & 13.0 \\
& $1997-2000$ & 17.0 & $11.0 \pm 3.0$ & 12.0 \\
& $2000-2004$ & 15.0 & $10.0 \pm 3.0$ & 11.0 \\
& $2004-2008$ & 13.0 & $9.0 \pm 3.0$ & 10.0 \\
& $1994-1997$ & 12.0 & $6.0 \pm 3.0$ & 6.0 \\
5 & $1997-2000$ & 6.0 & $4.0 \pm 2.0$ & 6.0 \\
& $2000-2004$ & 2.0 & $3.0 \pm 1.0$ & 6.0 \\
& $2004-2008$ & 7.0 & $2.0 \pm 3.0$ & 5.0 \\
7 & $1994-1997$ & 9.0 & $6.0 \pm 3.0$ & 8.0 \\
& $1997-2000$ & 15.0 & $7.0 \pm 3.0$ & 9.0 \\
& $2000-2004$ & 6.0 & $5.0 \pm 3.0$ & 6.0 \\
& $2004-2008$ & 4.0 & $4.0 \pm 3.0$ & 6.0 \\
& $1994-1997$ & 5.0 & $10.0 \pm 3.0$ & 11.0 \\
10 & $1997-2000$ & 20.0 & $9.0 \pm 3.0$ & 14.0 \\
& $2000-2004$ & 16.0 & $9.0 \pm 3.0$ & 10.0 \\
& $2004-2008$ & 20.0 & $7.0 \pm 3.0$ & 11.0 \\
\hline
\end{tabular}

* Standard deviation.

Still according to Table 4, there was an underestimation in the number of dead trees regarding the plots, and the confidence interval in plot 10 did not match the observed average. The largest underestimation of the number of dead trees in plots 3 and 10 was observed in Methodology 2.

\section{CONCLUSION}

It can be concluded that the estimates of mortality for tree group (Methodology 2) is more consistent than using a dichotomous variable in a logistic model (Methodology 1).

\section{SUBMISSION STATUS}

Received: 30 Sept. 2017

Accepted: 30 Aug. 2019

Associate editor: Emanuel José Gomes de Araújo

(D) 0000-0003-0363-4888

\section{CORRESPONDENCE TO}

\section{Lívia Figueiredo}

Rua Cel. José Porfírio, 2.515, Esplanada do Xingu, CEP 68372-040, Altamira, PA, Brasil

e-mail: liviatmf@ufpa.br

\section{FINANCIAL SUPPORT}

This study was financed in part by the Coordenação de Aperfeiçoamento de Pessoal de Nível Superior (Capes).

\section{REFERENCES}

Campos JCC, Leite HG. Mensuração florestal: perguntas e respostas. 5th ed. Viçosa: UFV; 2017. p. 636.

Castro RVO, Soares CPB, Leite HG, Souza AL, Martins FB, Nogueira GS et al. Competição em nível de árvore individual em uma floresta estacional semidecidual. Silva Lusitana 2014; 22(1): 43-66.

Castro RVO, Soares CPB, Leite HG, Souza AL, Martins FB, Nogueira GS et al. Artificial neural networks effectiveness to estimate mortality in a Semi-Deciduous Seasonal Forest. Australian Journal of Basic and Applied Scienses 2015; 9(5): 435-444.

Crecente-Campo F, Marshall P, Rodríguez-Soalleiro R. Modelling non-catastrophic individual-tree mortality for Pinus radiata plantations in northwestern Spain. Forest Ecology and Management 2009; 257(6): 1542-1550. 10.1016/j.foreco.2009.01.007

Cunha TA, Finger CAG. Competição assimétrica e o incremento diamétrico de árvores individuais de Cedrela odorata L. na Amazônia ocidental. Acta Amazonica 2013; 43(1): 9-18. 10.1590/S004459672013000100002

Ferreira RLC, Souza AL, Jesus RM. Ingresso e mortalidade em floresta secundária de transição. Revista Árvore 1998; 22(2): 155-162.

Figueiredo LTM, Soares CPB, Souza AL, Martins SV. Alterações florísticas em uma floresta Estacional Semidecidual no município de Viçosa, MG, entre 1994 e 2008. Floresta 2013; 43(2): 169-180. 10.5380/rf.v43i2.28869

Flewelling JW, Monserud RA. Comparing methods for modelling tree mortality. In: RMRS-P-25: Second Forest Vegetation Simulator Conference; 2002. Fort Collins: USDA; 2002. p. 168-177.

Gandolfi S, Leitão Filho HF, Bezerra, CL. Levantamento florístico e caráter sucessional de espécies arbustivo-arbóreas de uma floresta Mesófila Semidecídua no município de Guarulhos, SP. Revista Brasileira de Biologia 1995; 55(4): 753-767.

Glover GR, Hool JN. A basal area ratio predictor of loblolly pine plantation mortality. Forest Science 1979; 25(2): 275-282. 10.1093/ forestscience/25.2.275

Gujarati DN, Porter DC. Econometria básica. 5th ed. Porto Alegre: Bookman; 2011.

Hasenauer H, editor. Sustainable forest management: growth models for Europe. New York: Springer-Verlag; 2006.

Ma W, Lei X. Nonlinear simultaneous equations for individual-tree diameter growth and mortality model of natural Mongolian oak forests in northeast China. Forests 2015; 6(6): 2261-2280. 10.3390/f6062261

Martins FB, Soares CPB, Leite HG, Souza AL, Castro RVO. Índices de competição em árvores individuais de eucalipto. Pesquisa Agropecuária Brasileira 2011; 46(9): 1089-1098. 10.1590/S0100204X2011000900017

Monserud RA. Simulation of forest tree mortality. Forest Science 1976; 22(4): 438-444. 10.1093/forestscience/22.4.438

Monserud RA, Sterba H. Modeling individual tree mortality for Austrian forest species. Forest Ecology and Management 1999; 113 (2-3): 109-123. 10.1016/S0378-1127(98)00419-8 
Pretzsch H, Biber P, Durský J. The single tree-based stand simulator Silva: construction, application and evaluation. Forest Ecology and Management 2002; 162(1): 3-21. 10.1016/S0378-1127(02)00047-6

Rolim SG, Couto HTZ, Jesus RM. Mortalidade e recrutamento de árvores na Floresta Atlântica de Linhares. Scientia Forestalis 1999; 55: 49-69.

Rossi LMB, Koehler HS, Sanquetta CR, Arce JE. Modelagem de mortalidade em florestas naturais. Revista Floresta 2007; 37(2): 275-291. 10.5380/rf.v37i2.8656

Silva JNM. The behavior of tropical rain forest of the Brazilian Amazon after logging [thesis]. Oxford: University of Oxford; 1989. 302 p.

Soares CPB, Gezan SA, Silva GF, Castro RVO. Individual-tree growth and mortality models for a Semideciduous Atlantic forest in Brazil. Australian Journal of Basic and Applied Sciences 2015; 9(11): 542-552.

Sokal RR, Rohlf FJ. Biometry: The principles and practice of statistics in biological research. 1st ed. San Francisco: Freeman and Company; 1969.
Statsoft INC. Statistica for Windows (Data Analysis Software System). Version 12. Statsoft, Tulsa. Oklahoma; 2013.

Vanclay JK. Modelling forest growth and yield: applications to mixed tropical forests. Copenhagen: CAB International; 1994.

West PW. Simulation of diameter growth and mortality in regrowth Eucalypt forest of southern Tasmania. Forest Science 1981; 27(3): 603-616. 10.1093/forestscience/27.3.603

Weiskittel AR, Hann DW, Kershaw JA Jr, Vanclay JK. Forest growth and yield modeling. Oxford: John Wiley \& Sons; 2011.

Williamson GB, Mesquita RCG, Ickes K, Ganade G. Estratégias de colonização de árvores pioneiras nos Neotrópicos. In: Gascon C, Moutinho P, editors. Floresta Amazônica: dinâmica, regeneração e manejo. Manaus: INPA; 1998. p. 131-143.

Yao X, Titus SJ, Macdonald SE. A generalized logistic model of individual tree mortality for aspen, white spruce, and lodgepole pine in Alberta mixedwood forests. Canadian Journal of Forest Research 2001; 31(2): 283-291. 10.1139/x00-162 